\title{
Seismic hazard assessment in Polyphyto Dam area (NW Greece) and its relation with the "unexpected" earthquake of 13 May 1995 $\left(M_{\mathrm{s}}=6.5, \mathrm{NW}\right.$ Greece $)$
}

\author{
K. Pavlou ${ }^{1}$, G. Kaviris ${ }^{1}$, K. Chousianitis ${ }^{2}$, G. Drakatos ${ }^{2}$, V. Kouskouna ${ }^{1}$, and K. Makropoulos ${ }^{1,2}$ \\ ${ }^{1}$ Department of Geophysics, University of Athens, Panepistimiopolis, Zografou, 15784, Athens, Greece \\ ${ }^{2}$ Geodynamic Institute, National Observatory of Athens, Lofos Nymfon, Thission, 11810, Athens, Greece
}

Correspondence to: K. Pavlou (kpavlou@geol.uoa.gr)

Received: 25 October 2012 - Accepted: 12 December 2012 - Published: 25 January 2013

\begin{abstract}
Seismic hazard assessment and seismicity changes are investigated in the Kozani-Grevena area, at the western margin of internal Hellenides in NW Greece. The region is of great interest, since it was characterized by very low seismic activity until 1995, when the "unexpected" Kozani-Grevena earthquake $\left(M_{\mathrm{S}}=6.5\right)$ occurred. This event is of significant importance for Greece, since it, along with the 1999 Athens earthquake, initiated the modification of the Greek Building Code. In order to detect any seismicity changes, the seismicity of the region was divided into three time windows: the first up to 1973, the second from 1900 to 1994 and the third covering the entire instrumental period.

For the above mentioned time windows, seismic hazard assessment was performed using the extreme values method. The results indicate an increase of the peak ground acceleration (PGA) values after the impoundment, with the exception of the area in the vicinity of the NE edge of the Dam. Before the occurrence of the 1995 event, the epicentral region also exhibited higher PGA values than before the impoundment. The most significant increase in PGA values is observed SE of the Polyphyto artificial lake, where the largest values are observed for the second and the third period. The coincident increase in the number of earthquakes and in the PGA values may be attributed to the impoundment of the Polyphyto Dam.
\end{abstract}

The maximum expected magnitude is calculated by the extreme values method and Gumbel's third asymptotic distribution. The results reveal similar values of maximum expected magnitudes $\left(M_{\max }=6.5\right)$, independent of the seismicity rate, indicating that the 13 May 1995 earthquake was not an "unexpected" event, since the magnitude of an oncoming earthquake depends mainly on the tectonics of the region and the characteristics of the active faults.

\section{Introduction}

The Public Power Corporation (PPC) of Greece has established three Dams (namely, Polyphyto, Sfikia and Asomata) on Aliakmonas River (NW Greece), downstream of each other, with Polyphyto Dam being the first and largest with a height of $112 \mathrm{~m}$, maximum water level height $h=289 \mathrm{~m}$, maximum volume $V=1220 \times 10^{6} \mathrm{~m}^{3}$ and the first filling took place in January 1974 (Fig. 1).

Originally, the broader area was classified as a region of low seismicity (R.D., 1959; Papazachos and Comninakis, 1982; Makropoulos and Burton, 1984, 1985a; Papazachos and Papazachou, 1989) until 13 May 1995, when a strong earthquake of $M_{\mathrm{S}}=6.5$ occurred between the cities of Kozani and Grevena, at a distance of $18 \mathrm{~km}$ from the southern edge of the Polyphyto artificial lake. This area is close to the epicenter of the $M_{\mathrm{s}}=5.4$ earthquake that took place on 25 October 1984 during the Asomata reservoir initial filling. The 1995 event caused significant damage to parts of Kozani and Grevena cities and to a number of villages located between them (Carydis et al., 1995; Lekkas et al., 1996). Approximately 5000 houses were severely damaged. Moreover, this event triggered a lengthy dispute as to whether it was induced by the impoundment of the Polyphyto artificial lake or caused by tectonic movements (Pavlides et al., 1995; Meyer et al., 1996; Hatzfeld et al., 1997; Drakatos et al., 1998; Papanastassiou et al., 1998; Pavlou, 2011).

The above controversy coupled with (a) the fact that the area of Kozani-Grevena is characterized as the energy pillar of Greece, because besides the main hydroelectric power plants, the PPC operates four very large lignite power plants; (b) the fact that many major industries are located in the region and (c) the gathering of new macroseismic data 


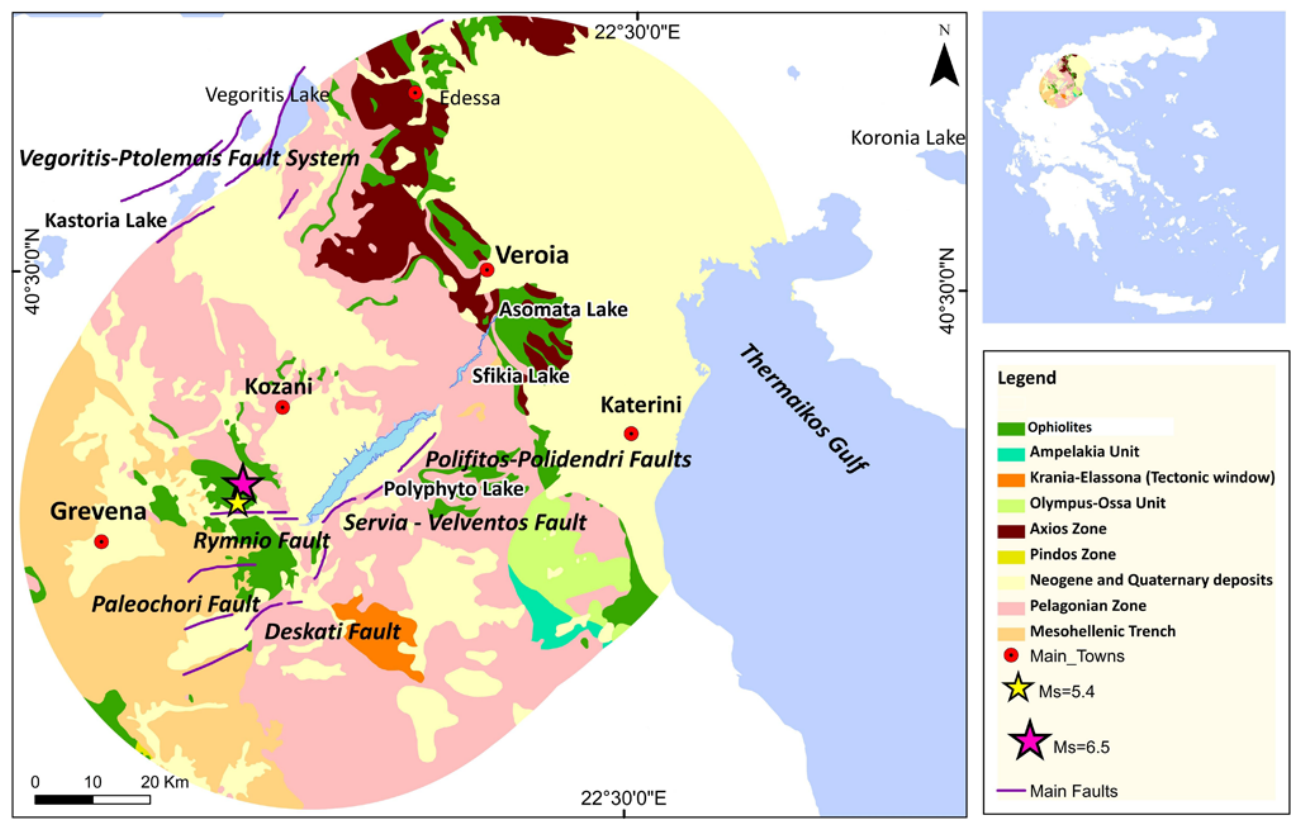

Fig. 1. Map of the main geotectonic and fault zones of the broader area (50 km around the artificial lakes). A location map of the region is shown (upper right). Yellow and purple stars denote the epicenters of the 25 October 1984 and 13 May 1995 earthquakes, respectively.

including the 1995 destructive Kozani-Grevena Earthquake and more complete and homogeneous instrumental earthquake catalogue, motivated the present study in an attempt to get insight into the seismicity rate changes and the seismic hazard of the area.

\section{Geotectonic setting}

The area of interest in this study belongs to a tectonic basin of the Pelagonian zone (Fig. 1), consisting of metamorphic rocks (crystalline substratum) covered by carbonate rocks and flysch (Mercier, 1966; Mountrakis, 1986; Katerinopoulos et al., 1994). The south-western part is covered by ophiolites (Jurassic-Upper Cretaceous) and molassic sediments which belong to the Mesohellenic trench, while the northern part of the broader area (up to $50 \mathrm{~km}$ around the artificial lakes) is covered by carbonate rocks, belonging to the Axios zone, and ophiolites (Doutsos, 1980). Two main faults (Fig. 1) dominate the broader Polyphyto reservoir area. The first is the $70 \mathrm{~km}$ long Aliakmonas Fault zone, with several sub-parallel faults that strike ENE-WSW to NE-SW, parallel to the Polyphyto artificial lake. The major recognized segments of the Aliakmonas Fault zone are the Palaeochori and Rymnio, the Serbia-Velventos and the Polifitos-Polidendri Faults. The second is the Vegoritis-Ptolemais fault system with a NE-SW strike (Mountrakis et al., 2006).
Table 1. Results of the completeness test of the Makropoulos et al. (2012) instrumental earthquake catalogue.

\begin{tabular}{lcc}
\hline $\begin{array}{l}\text { Surface } \\
\text { wave } \\
\text { magnitude }\end{array}$ & $\begin{array}{c}\text { Time required for } \\
\text { stable recurrence } \\
\text { rate (yr) }\end{array}$ & $\begin{array}{c}\text { Period of } \\
\text { completely } \\
\text { reported events }\end{array}$ \\
\hline$M_{\mathrm{S}} \geq 4.0$ & 5 & $1976-2009$ \\
$M_{\mathrm{S}} \geq 4.5$ & 20 & $1950-2009$ \\
$M_{\mathrm{S}} \geq 5.0$ & 25 & $1940-2009$ \\
$M_{\mathrm{S}} \geq 5.5$ & 45 & $1911-2009$ \\
$M_{\mathrm{S}} \geq 6.0$ & 60 & $1900-2009$ \\
\hline
\end{tabular}

\section{Data and analysis}

Several earthquake catalogues contain data concerning the seismicity of Greece (Shebalin et al., 1974; Makropoulos and Burton, 1981; Papazachos and Comninakis, 1982; Makropoulos et al., 1989; Papazachos and Papazachou, 1989, 2003; Makropoulos et al., 2012). It is well established that the homogeneity of an earthquake catalogue and the respective magnitude of completeness versus time play a key role in the assessment of the seismic hazard. Periods of detection increase due to seismological station expansions throughout the instrumental period and the addition of the Kozani (NOA) seismological station in 1994 should be considered as artificial or man-made rate changes (Chouliaras and Stavtrakakis, 1997; Chouliaras, 2009). In the present study, the epicenters and source parameters are obtained from the catalogue of Makropoulos et al. (2012), an updated 
earthquake catalogue for Greece and adjacent areas, covering the time span 1900-2009. Table 1 summarizes the completeness (time intervals in which a certain magnitude range is likely to be completely reported) of the Makropoulos et al. (2012) catalogue, obtained using the method introduced by Stepp (1971), as well as the time period required to restore a stable release rate of a specific range of magnitudes. This interval is a function of magnitude class, being successively longer with each higher maximum magnitude class. Events with $M_{\mathrm{s}} \geq 4.0$ are completely reported for the last $34 \mathrm{yr}$ of the catalogue (1976-2009). Earthquakes of $M_{\mathrm{S}} \geq 4.5$ are completely reported for the last $60 \mathrm{yr}$ of the catalogue and events with $M_{\mathrm{s}} \geq 5.0$ and $M_{\mathrm{s}} \geq 5.5$ after 1940 and 1911, respectively. No earthquake with $M_{\mathrm{s}} \geq 6.0$ seems to have been omitted for the whole period (i.e. 1900-2009). The epicenters of 113 earthquakes with $M_{\mathrm{s}} \geq 4.0$ located in the study area since 1900 within $50 \mathrm{~km}$ around the three artificial lakes are presented in Fig. 2. Significant seismicity is observed mainly southwest of the Dam, in the region where the southern fault segments of the Aliakmonas Fault zone are mapped (Fig. 1).

The faults direction (E-W), which are located in the southwestern region of the Polyphyto artificial lake, seems to facilitate the transfer of the pore pressure due to the annual water level fluctuations, leading to a reduction of fault shear strength $(S)$ (Withers and Nyland, 1976). The strength change $(\Delta S)$ is defined by the following equation (Bell and Nur, 1978):

$\Delta S=\mu f\left(\Delta \sigma_{n}-\Delta p\right)-\Delta \tau$

where $\mu f$ is the coefficient of friction, $\Delta \tau, \Delta \sigma_{n}$ and $\Delta p$ are changes in shear stress on the fault in the direction of slip, normal stress across the fault and pore pressure, respectively.

The largest earthquake in the region is the $M_{\mathrm{S}}=6.51995$ Kozani-Grevena earthquake, which was followed by significant aftershock activity (Hatzfeld et al., 1997). Prior to this earthquake, the major events of the region were the $M_{\mathrm{S}}=5.5$ earthquake on 7 December 1922, $23 \mathrm{~km} \mathrm{SW}$ of the Kozani 1995 earthquake epicenter and the $M_{\mathrm{S}}=5.5$ earthquake that occurred on 25 March 1943, 32 km NW from the Polyphyto Dam.

In the present study, we investigate the seismicity during the instrumental period (from 1900 until 2009) and the earthquake catalogue (113 events) was divided into three time windows: the first, consisting of 4 events from 1900 up to 1973, the second from 1900 up to 1994, consisting of 15 more events, and the third from 1900 up to 2009, consisting of 94 additional events. The selection criteria were the impoundment of the Polyphyto reservoir in 1974 and the occurrence of the Kozani-Grevena earthquake in 1995. The spatial distribution of the seismic activity for distances up to $50 \mathrm{~km}$ is illustrated in Fig. 2.

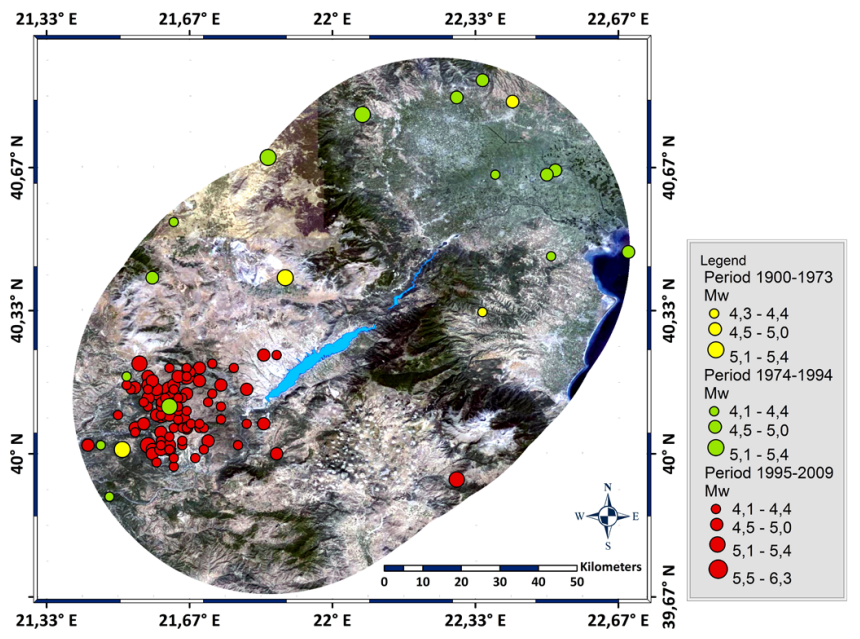

Fig. 2. Spatial distribution of seismicity $\left(M_{\mathrm{S}} \geq 4\right)$ for the period 1900-2009.

\section{Results}

\subsection{Seismic hazard assessment}

The reliable estimation of seismic hazard parameters, such as peak ground acceleration (PGA), is an important result for earthquake resistant planning and risk mitigation and essential for defining proper engineering parameters, such as spectral velocity and elastic input energy.

The most suitable statistical approach for the available sample is the theory of extreme values which was introduced by Gumbel (1958) and has extensively been applied to seismic hazard problems (Makropoulos, 1978; Burton, 1979; Makropoulos and Burton, 1985a, b; Tsapanos and Burton, 1991; Burton et al., 2003; Ozturk et al., 2008). The advantage of the applied methodology in the case of the present study is that only an earthquake catalogue is used. On the contrary, seismotectonic probabilistic methods take into account the tectonic regime of the locus of seismogenic sources, which are used in the distribution laws. For each seismogenic source the coefficients $a$ and $b$ of the Gutenberg-Richter magnitudefrequency relation distribution must be determined, which would not be reliable for all three time periods (especially for the first up to 1993). Extreme values theory follows three different types of asymptote distributions which do not depend on the parent population distribution. The estimation of maximum expected ground motion parameters, including PGA, requires the application of the first asymptote, i.e. of the Eq. (2):

$G^{I}(x)=\exp (-\exp (-a(x-u))), a>0$

where $G(x)$ represents the probability that the variable $x$ is an annual extreme, that is, $G(x)$ gives the annual probability that $x$ is not exceeded. The parameter $u$ is a characteristic value of the variable $x$ and has a probability $G(u)=1 / e$ of being an annual extreme. 


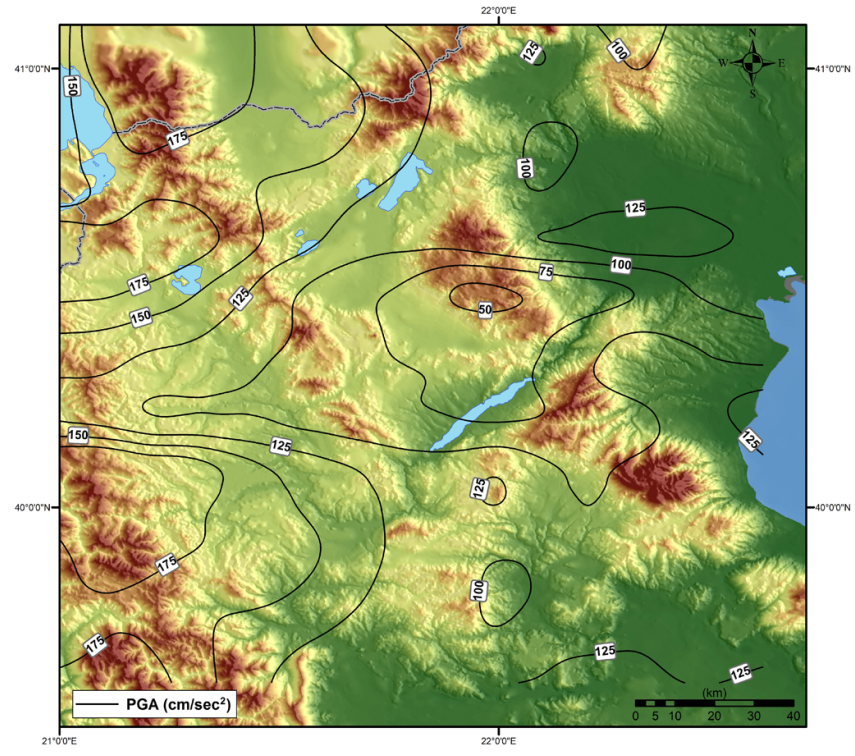

Fig. 3. Peak ground acceleration $\left(\mathrm{cm} \mathrm{s}^{-2}\right)$ with probability $90 \%$ of not being exceeded in $50 \mathrm{yr}$ (Return Period $=475 \mathrm{yr}$ ) for the period 1900-1973.

The attenuation law that is used in the present study is the one calculated for Greece by Makropoulos (1978):

$A=2164 e^{0.7 M} \cdot(R+20)^{-1.8}$

where $A$ is acceleration in $\mathrm{cm} \mathrm{s}^{-2}, M$ the earthquake magnitude and $R$ the hypocentral distance in $\mathrm{km}$.

It is worth noting that the above is an average relation that gives acceleration values between the ones obtained using the relations proposed for Greece by Theodulidis and $\mathrm{Pa}$ pazachos (1992) and Margaris et al. (2001), as shown by Papaioannou et al. (2008).

The values of the peak ground acceleration (PGA) with a $90 \%$ probability of no exceedance in $50 \mathrm{yr}$, corresponding to a return period of $475 \mathrm{yr}$, in the vicinity of the Polyphyto Dam are calculated using the extreme values method and the HAZAN software (Makropoulos and Burton, 1986). Three time periods were selected, in order to examine the effect of the Dam loading and the water level fluctuation to the seismic hazard of the region. The first is the period before the impoundment of the Dam, 1900-1973, the second lasts until the occurrence of the 1995 Kozani-Grevena Earthquake, 19001994, and the third refers to the whole period, 1900-2009. The data used for seismic hazard assessment are limited to distances up to $70 \mathrm{~km}$ around the three artificial lakes. PGA values for the first period (Fig. 3) vary between $50 \mathrm{~cm} \mathrm{~s}^{-2}$ and $175 \mathrm{~cm} \mathrm{~s}^{-2}$. The highest values are obtained west of the Dam, while values of $50 \mathrm{~cm} \mathrm{~s}^{-2}$ are observed to the north.

The contour map of the PGA results with a $90 \%$ probability of no exceedance in $50 \mathrm{yr}$ for the second period (19001994) is presented in Fig. 4. It is observed that the values, ranging between $75 \mathrm{~cm} \mathrm{~s}^{-2}$ and $200 \mathrm{~cm} \mathrm{~s}^{-2}$, are higher when

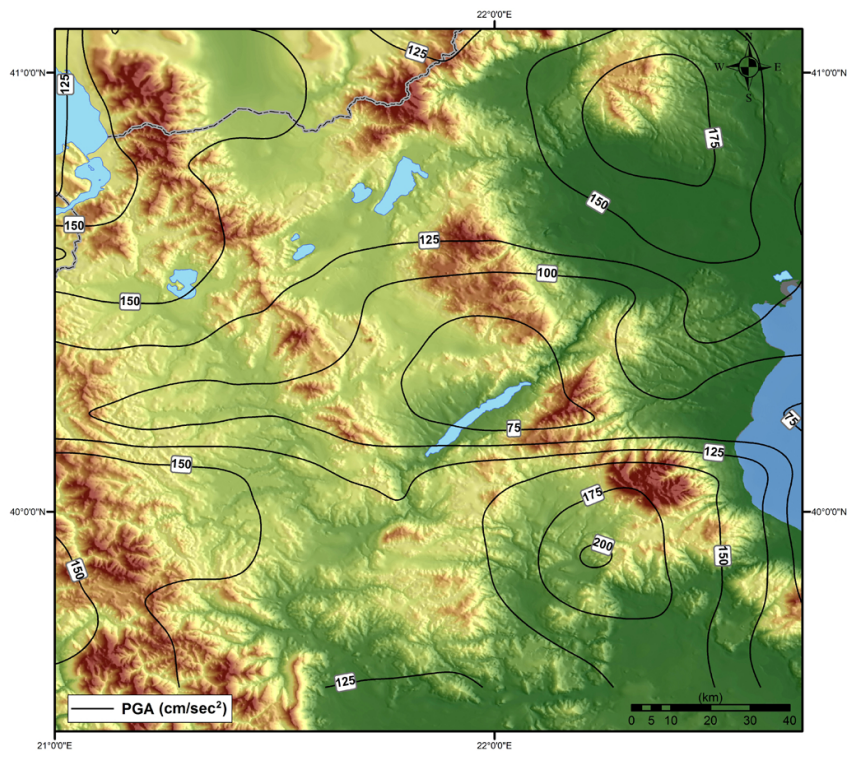

Fig. 4. Peak ground acceleration $\left(\mathrm{cm} \mathrm{s}^{-2}\right)$ with probability $90 \%$ of not being exceeded in $50 \mathrm{yr}$ (Return Period $=475 \mathrm{yr}$ ) for the period 1900-1994.

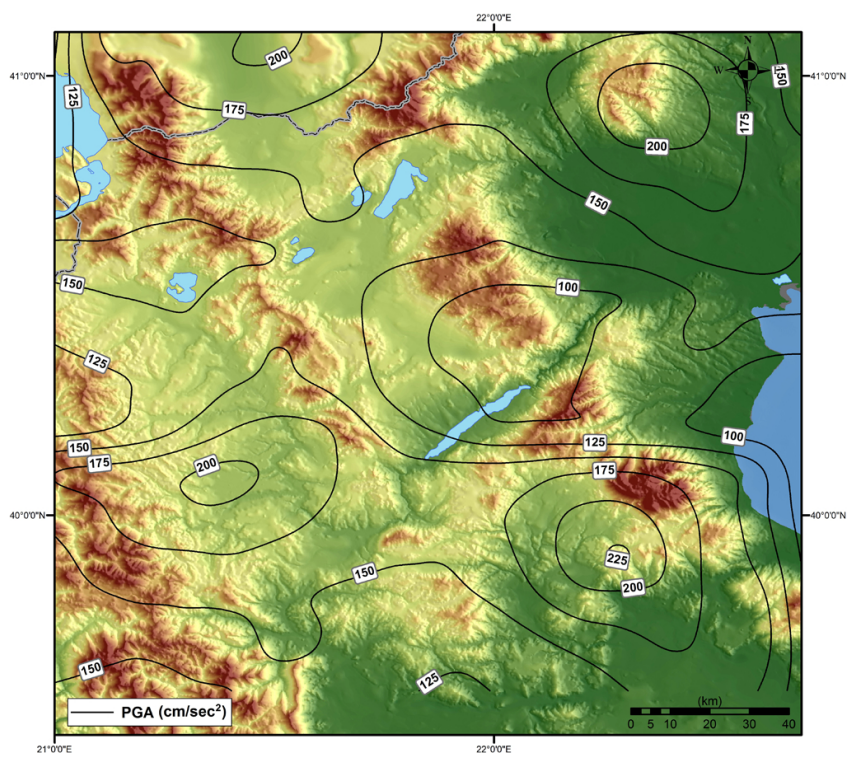

Fig. 5. Peak ground acceleration $\left(\mathrm{cm} \mathrm{s}^{-2}\right)$ with probability $90 \%$ of not being exceeded in $50 \mathrm{yr}$ (Return Period $=475 \mathrm{yr}$ ) for the period 1900-2009.

compared to the ones determined for the first period. The maximum PGA values are obtained SE of the Dam, at a distance of approximately $40 \mathrm{~km}$, while minimum values are obtained within the Dam and its vicinity.

Seismic hazard analysis was also performed for the entire instrumental period (i.e. 1900-2009) and the results are presented in Fig. 5. The PGA values are found to be in the range between $100 \mathrm{~cm} \mathrm{~s}^{-2}$ and $225 \mathrm{~cm} \mathrm{~s}^{-2}$. The lowest values are observed to be located close to the NE part of the 


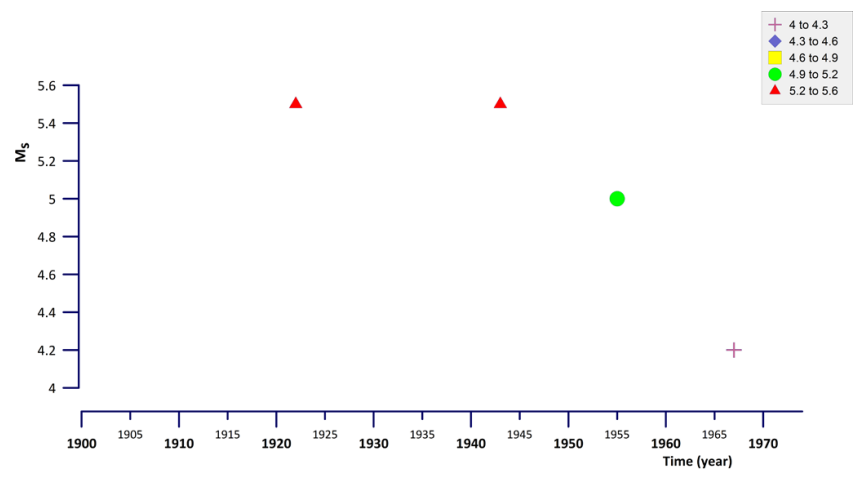

(a)

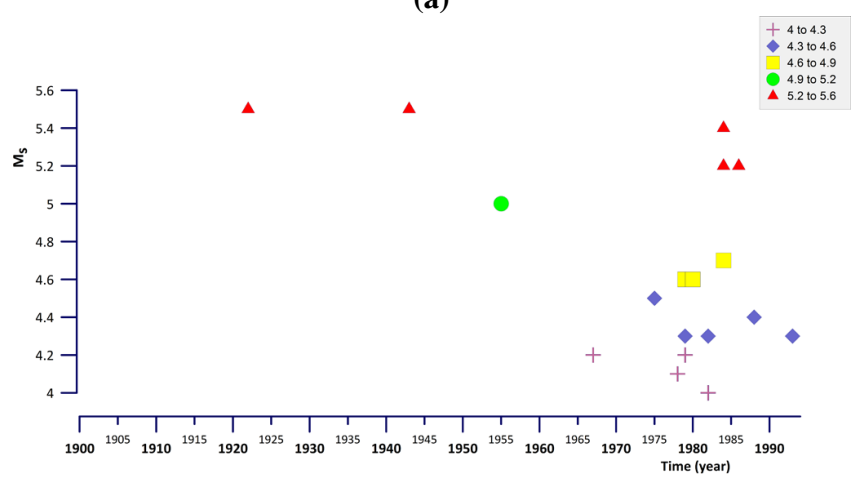

(b)

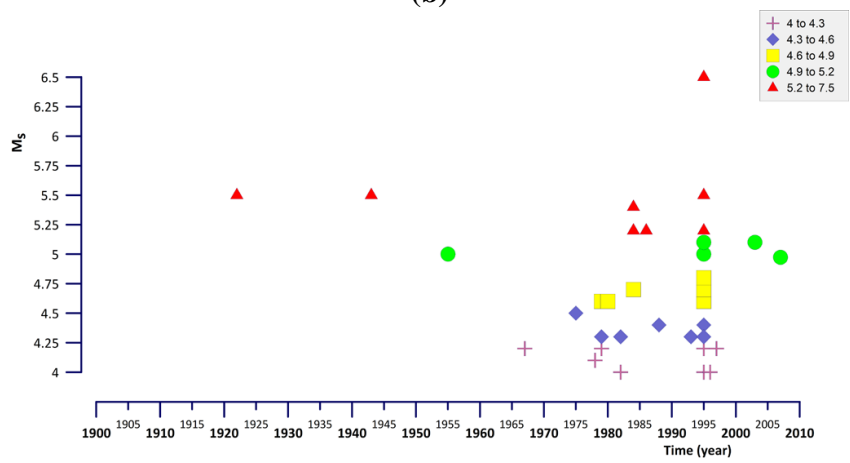

(c)

Fig. 6. (a) Temporal distribution by magnitude for the period: 19001973. (b) Temporal distribution by magnitude for the period: 1900 1994. (c) Temporal distribution by magnitude for the period: 1900 2009.

Dam, while the highest $\left(200-225 \mathrm{~cm} \mathrm{~s}^{-2}\right)$ to the $\mathrm{W}$ and SE, within distances that reach $40 \mathrm{~km}$ from the Polyphyto Dam. It should be noted that these values are larger in comparison to those provided by the new Greek Building Code (EAK, 2003), as the study area is located in Zone I, corresponding to PGA values $0.16 \mathrm{~g}\left(157 \mathrm{~cm} \mathrm{~s}^{-2}\right)$.

\subsection{Seismicity rate changes}

The temporal distribution of earthquake magnitudes has been examined for the three selected overlapping time periods and the results are presented in Fig. 6. Four moderate earthquakes with $M_{\mathrm{S}}=5.5(1922), M_{\mathrm{S}}=5.5(1943), M_{\mathrm{S}}=5.0(1955)$ and $M_{\mathrm{S}}=4.2(1967)$ occurred within $50 \mathrm{~km}$ around the three artificial lakes until 1973, while significant increase concerning the number of earthquakes is observed after 1974.

It is worth noting that the initiation of the seismicity increase coincides with the impoundment of the largest reservoir in Polyphyto, in 1974. Ten seismic events with magnitudes $4.0<M_{\mathrm{S}}<5.2$ occurred from 1900 until September 1984 as shown in Fig. 6b. The filling of the two smaller artificial lakes started on 10 October 1984 in the Asomata Dam and on 13 March 1985 in the Sfikia Dam and two earthquakes with magnitudes $M_{\mathrm{S}}=5.4$ and $M_{\mathrm{S}}=5.2$ occurred on 25 October 1984 and 18 February 1986, respectively. In addition, during the above period (i.e. 1984-1986) several microearthquakes were recorded by the local network operated by the Public Power Corporation and these events are well correlated with the water level fluctuations as demonstrated by Pavlou (2011). The observed seismicity increase appears to have been initiated coincident with the time of impoundment of the three artificial lakes (i.e. Polyphyto, Sfikia and Asomata reservoirs).

The occurrence of the Kozani-Grevena 1995 earthquake dominates the 1900-2009 period. However, four moderate earthquakes with magnitudes $4.0 \leq M_{\mathrm{S}} \leq 5.1$ took place at distances that reach $50 \mathrm{~km}$ around the three reservoirs in 1996, 1997, 2003 and 2007 (Fig. 6c). It should be stressed that the occurrence of these events also coincides with the highest water level periods of the Polyphyto Dam (Pavlou, 2011). The last moderate earthquake with magnitude $M_{\mathrm{S}}=$ 5.0 occurred in July 2007.

The spatial distribution of the recorded seismicity for the three different periods (i.e. 1900-1973, 1900-1994 and 1900-2009) is illustrated in Fig. 7. The seismicity prior to the impoundment of the three reservoirs (i.e. 1900-1973) is presented in the map of Fig. 7a. During this period only four events, with magnitude $M_{\mathrm{s}} \geq 4.2$ within distances up to $50 \mathrm{~km}$ around the artificial lakes are observed. Increased seismicity around the three reservoirs is observed in the second period (i.e. 1900-1994), during which the impoundment of the three reservoirs took place (Fig. 7b). The seismicity increase occurs after 1994 (third period, i.e. 1900-2009) and is mainly located to the southwest of the Polyphyto artificial lake, in the epicentral area of the 1995 Kozani-Grevena earthquake (Fig. 7c).

\subsection{Maximum expected earthquake}

The extreme values method (Gumbel, 1958) was also used to estimate the 50-year most-probable maximum earthquake magnitude. This method has been used to evaluate the seismic hazard of Greece in terms of magnitude (Makropoulos and Burton, 1985a). After successive tests of the asymptotic distributions of the first and third type, the third asymptote approach was chosen, since it produced more realistic and robust solutions, regarding the standard deviation values. The same three time periods that were selected for the case of 

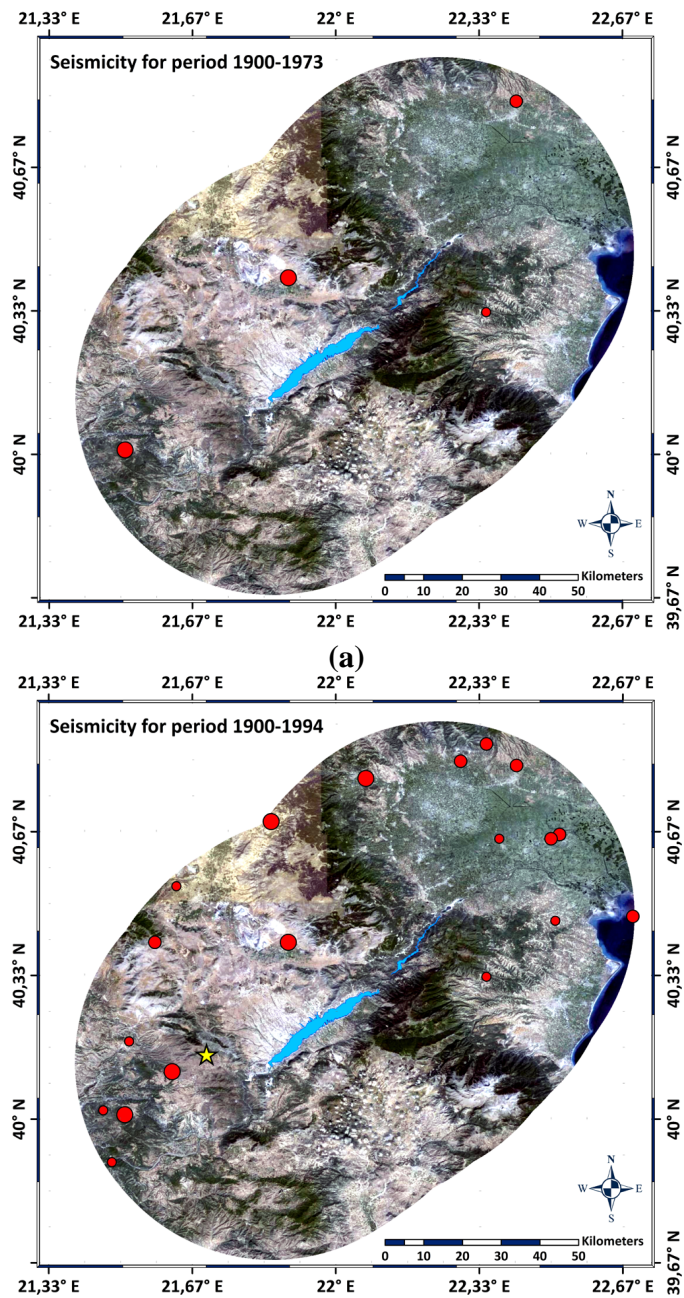

(b)

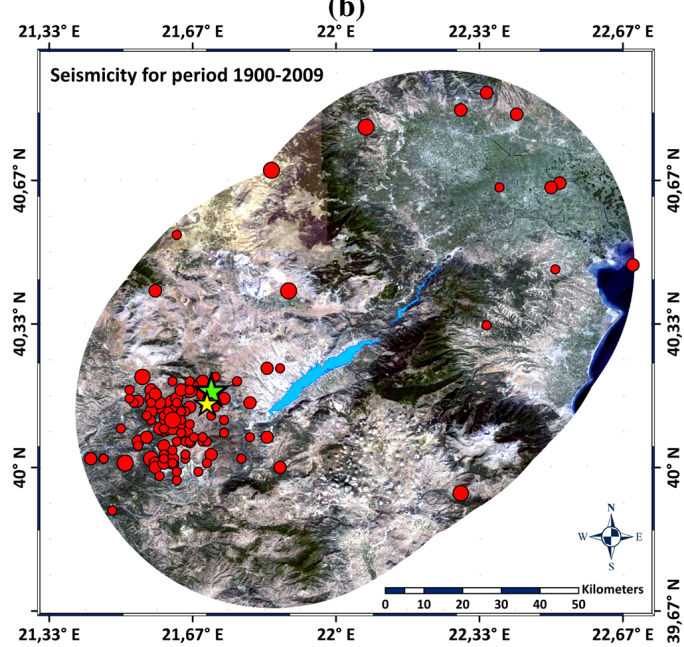

(c)

Fig. 7. (a) Spatial distribution of seismicity $\left(M_{\mathrm{S}} \geq 4\right)$ for the period: 1900-1973. (b) Spatial distribution of seismicity $\left(M_{\mathrm{S}} \geq 4\right)$ for the period: 1900-1994. (c) Spatial distribution of seismicity $\left(M_{\mathrm{S}} \geq 4\right)$ for the period: $1900-2009$.

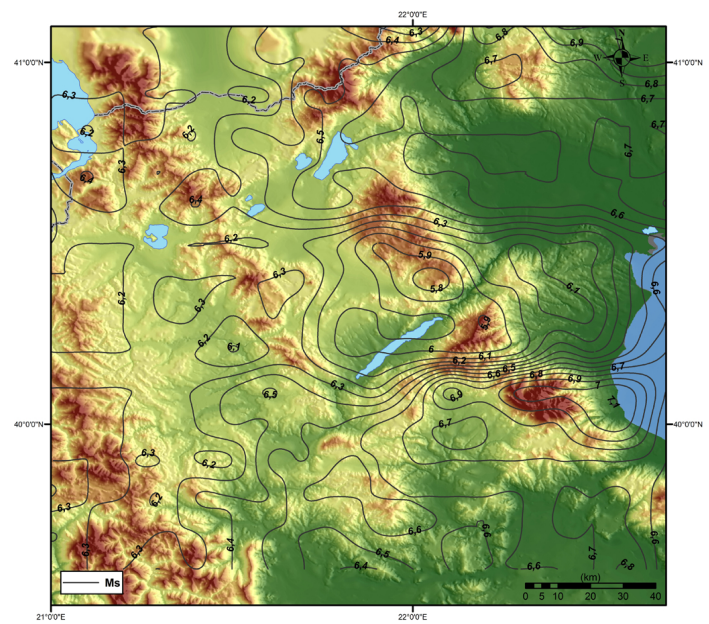

(a)

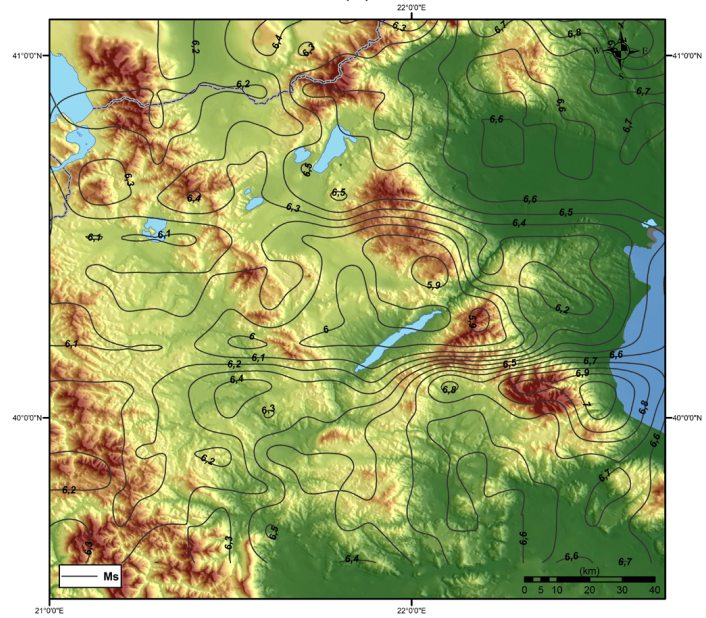

(b)

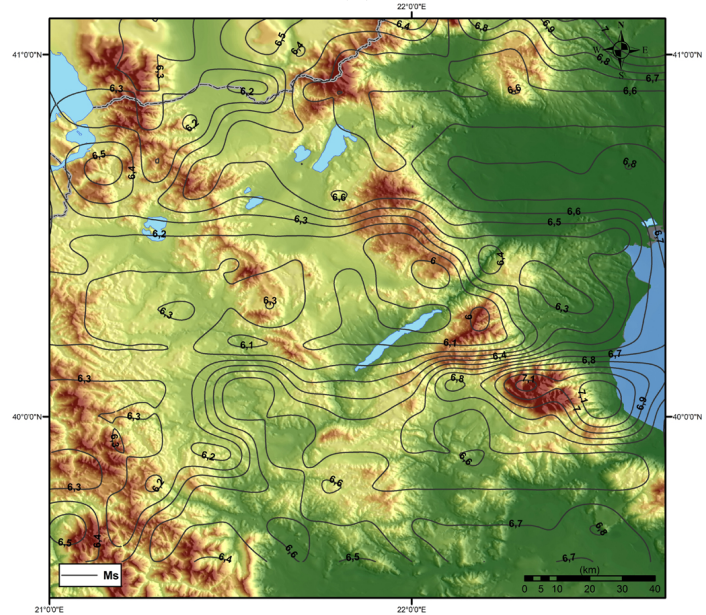

(c)

Fig. 8. (a) The 50-yr most-probable maximum earthquake magnitude for the period: 1900-1973. (b) The 50-yr most-probable maximum earthquake magnitude for the period: 1900-1994. (c) The 50yr most-probable maximum earthquake magnitude for the period: 1900-2009. 
the peak ground acceleration were considered to present the corresponding contour maps. The 50-yr most-probable maximum earthquake magnitude in the broader area of the Polyphyto Dam is presented in Fig. 8. It is evident that all maps reveal a similar pattern with the lowest values of the order of $M_{\mathrm{S}}=5.8$ close to the NE part of the Dam, and the highest, of the order of $M_{\mathrm{S}}=7.0$, within distances $40 \mathrm{~km} \mathrm{SE}$ from Polyphyto. The similarity in the estimated values of the maximum expected magnitude for all three time periods implies that the microseismicity increase after the impoundment of the Polyphyto artificial lake in 1974 was not capable of increasing the maximum expected magnitude, in contrast with PGA. This observation is explained by the fact that microseismicity increase is not able to raise the fault potential (i.e. maximum magnitude), but at close distances from the area of the microseismicity increase the PGA rises, since it is distance dependent due to the attenuation laws. That was the case after the impoundment of the Polyphyto Dam, where at close distances the microseismicity increase caused also increase in the PGA, in contrast to the maximum expected earthquake magnitude that remained unaffected. The second interesting result deduced from these maps is that, according to the hazard analysis, increased PGA values were calculated during the second period (1900-1994) in the area where the "unexpected" 1995 Kozani-Grevena earthquake occurred. This emphasizes the need of more detailed local seismic hazard analyses, as the one performed in the framework of the present study, because the coarse regional analyses are not able to detect small changes in magnitude/ground parameters, which sometimes are of great importance, as in the case of the 1995 Kozani-Grevena earthquake.

\section{Discussion}

The investigation of several earthquake catalogues (Makropoulos and Burton, 1981; Papazachos and Comninakis, 1982; Makropoulos et al., 1989; Papazachos and Papazachou, 1989) indicates that the Kozani area was characterized by a low seismic activity rate until the occurrence of the Kozani-Grevena earthquake in 1995. It is worth noting that the previous destructive event in this area occurred in 896 and caused considerable damage to the city of Veroia (Papazachos and Papazachou, 1989, 2003), located $22 \mathrm{~km}$ north of the Polyphyto Dam. Furthermore, the Greek Building Code was modified after the occurrences of the "unexpected" Kozani-Grevena (1995) and Athens (1999) earthquakes.

The distribution of seismicity by time and magnitude $\left(M_{\mathrm{S}} \geq 4\right)$ was studied for three selected overlapping periods (i.e. 1900-1973, 1900-1994 and 1900-2009). Detailed study of the first two periods reveals an appreciable increase of seismicity, initiated after the impoundment of the Polyphyto artificial lake (1974). It is worth noting that during the first period only four events with $M_{\mathrm{s}} \geq 4.0$ occurred within

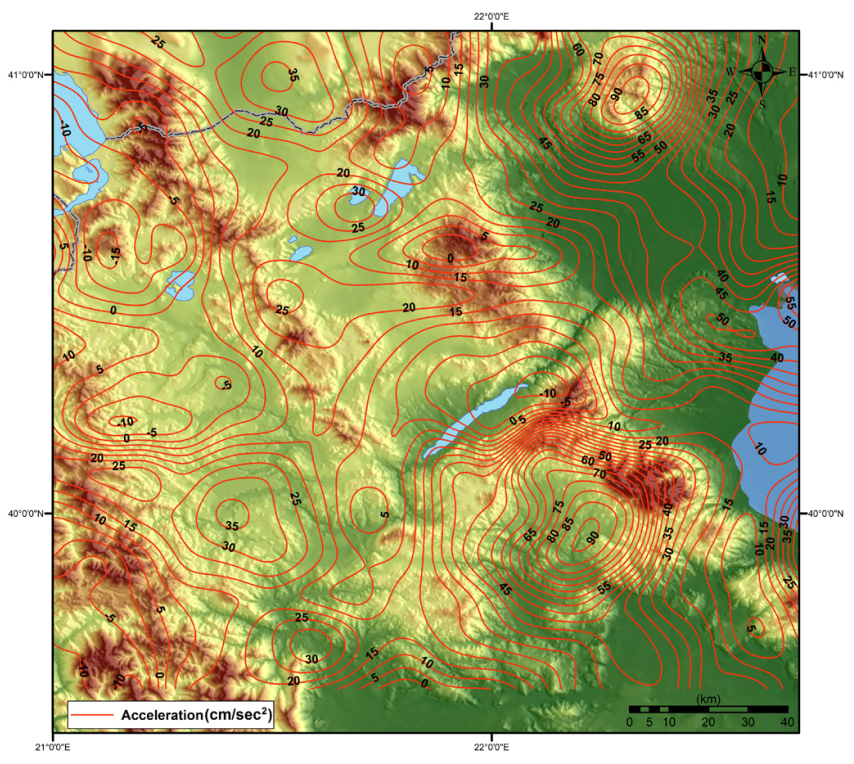

Fig. 9. Difference of Peak Ground Acceleration $\left(\mathrm{cm} \mathrm{s}^{-2}\right)$ values with probability $90 \%$ of not being exceeded in $50 \mathrm{yr}$ (Return Period $=475 \mathrm{yr}$ ) between the periods: PGA $1900-1994^{-}$ PGA 1900-1973.

distances up to $50 \mathrm{~km}$ around the three reservoirs, while during the second period fifteen more events took place. During the second period two significant seismic events with magnitudes $M_{\mathrm{S}}=5.4$ and $M_{\mathrm{S}}=5.2$ occurred on 25 October 1984 and 18 February 1986, respectively, after the first filling of the Asomata and Sfikia Dams. The seismic activity is mainly concentrated SW of the Polyphyto Lake, the area where the Kozani-Grevena earthquake (1995) took place. The number of earthquakes that occurred in the study region increased after the impoundment of the Polyphyto Dam (1974) and before the occurrence of the 1995 event. In addition to this result, the determined PGA values indicate a clear increase after the impoundment of the Dam (Fig. 9). The differences of PGA values, with a $90 \%$ probability of no exceedance in $50 \mathrm{yr}$, between the period before the impoundment (19001973) and the one before the Kozani-Grevena earthquake (1900-1994), have also been determined. It is worth noting that the PGA increase is also evident at the epicentral region of the Kozani-Grevena earthquake, before its occurrence. The largest increase $\left(90 \mathrm{~cm} \mathrm{~s}^{-2}\right)$ is observed SE of the Dam, where the highest PGA values are obtained for the second (1900-1994) and the third (1900-2009) time period (200 and $225 \mathrm{~cm} \mathrm{~s}^{-2}$, respectively). Within a $40 \mathrm{~km}$ distance, PGA values are observed to be lower close to the NE edge of the Dam.

The seismic hazard assessment by means of the extreme values method revealed that in the vicinity of the 13 May 1995 Kozani-Grevena earthquake $\left(M_{\mathrm{s}}=6.5\right)$, the 50-yr most-probable maximum earthquake magnitude for the period before its occurrence was $M_{\max } \leq 6.5$. This result 
highlighted the seismic potential of the area for an event of the order of 6.5 and proves that local seismic hazard analysis is able to reveal potentially seismic prone regions, such as the broader area of the Kozani-Hrevena earthquake.

It is therefore concluded that the 1995 Kozani-Grevena earthquake was not an "unexpected" event, but it is likely to have been accelerated due to the filling of the Polyphyto Dam. The impoundment of these artificial lakes did not affect the $M_{\text {max }}$, since the magnitude of an oncoming earthquake depends mainly on the tectonics of the region and the characteristics of the active faults, but can trigger and increase the rate of seismicity.

The calculated increase of both the number of earthquakes and of PGA values may be attributed to the impoundment and the water level fluctuations of the Polyphyto Dam due to the pore pressure increase (Talwani and Acree, 1985; Roeloffs, 1988; El Hariri et al., 2010). Nevertheless, these factors did not affect the magnitude of the 13 May 1995 event.

This earthquake, however, demonstrated clearly that the rate of seismicity alone is not a safe criterion to assess the seismic potential of a region. Only a detailed analysis contributes toward a reliable seismic hazard assessment. Had such studies been undertaken before 1995, they certainly would have revealed the potential risk of the active tectonic structures that ruptured during the 13 May 1995 seismic crisis.

Acknowledgements. The authors would like to thank both reviewers and the editor for constructive comments. This research was partly supported by the EPOS-PP project, Grant Agreement 262229.

Edited by: M. E. Contadakis

Reviewed by: two anonymous referees

\section{References}

Bell, M. L. and Nur, A.: Strength Changes Due to Reservoirinduced Pore Pressure and Application to Lake Oroville, J. Geophys. Res., 83, 4469-4483, 1978.

Burton, P. W.: Seismic risk in Southern Europe through to India examined using Gumbel's third distribution of extreme values, Geophys. J. R. Astr. Soc., 59, 249-80, 1979.

Burton, P. W., Xua, Y., Tselentis, G.-A., Sokos, E., and Aspinall, W.: Strong ground acceleration seismic hazard in Greece and neighboring regions, Soil Dynam. Earthq. Eng., 23, 159-181, 2003.

Carydis, G., Holevas, K., Lekkas, E., and Papadopoulos, T.: The Grevena (Central-North Greece) Earthquake Series of May 13, 1995, EERI Spec. Earth. Rep., 29, 1-4, 1995.

Chouliaras, G.: Investigating the earthquake catalog of the National Observatory of Athens, Nat. Hazards Earth Syst. Sci., 9, 905912, doi:10.5194/nhess-9-905-2009, 2009.

Chouliaras, G. and Stavrakakis, G.: Seismic source parameters from a new dial-up seismological network in Greece, Pure Appl. Geophys., 124, 1039-1050, 1997.
Doutsos, T.: Postalpine Geodynamik Thessaliens (Griechenland), Zeitschr. Deutsch. geol. Ges., 131, 685-698, 1980.

Drakatos, G., Papanastassiou, D., Papadopoulos, G., Skafida, H., and Stavrakakis, G.: Relationship between the 13 May 1995 Kozani-Grevena (NWGreece) earthquake and the Polyphyto artificial lake, Eng. Geol., 51, 65-74, 1998.

EAK: Greek Seismic Code, edited by: Earthquake Planning \& Protection Organization, Athens, Greece, 72 pp., 7 appendixes, 2003.

El Hariri, M., Abercrombie, R. E., Rowe, C. A., and do Nascimento, A. F.: The role of fluids in triggering earthquakes: observations from reservoir induced seismicity in Brazil, Geophys. J. Int., 181, 1566-1574, 2010.

Gumbel, E. J.: Statistics of Extremes. Columbia University Press, New York, 1958.

Hatzfeld, D., Karakostas, V., Ziazia, M., Selvaggi, G., Leborgne, S., Berge, C., Guiguet, R., Paul, A., Voidomatis, P., Diagourtas, D., Kassaras, I., Koutsikos, I., Makropoulos, K., Azzara, R., Di Bona, M., Baccheschi, S., Bernard, P., and Papaioannou, C.: The Kozani-Grevena (Greece) Earthquake of 13 May 1995. Revisited from a Detailed Seismological Study. Bull. Seismol. Soc. Am., 87, 463-473, 1997.

Katerinopoulos, A., Kokkinakis, A., and Kyriakopoylos, K.: Petrology and chemical characteristics of Deskati granitic rocks, Thessaly, Greece, B. Geol. Soc. Greece, XXX/3, 79-88, 1994.

Lekkas, E. L., Fountoulis, I. G., Lozios, S. G., Kranis, Ch. D., and Adamopoulou, E. I.: Neotectonic Implications of GrevenaKozani earthquake (May 13, 1995, W. Macedonia, Greece), International meeting on results of the May 131995 earthquake of West Macedonia: One year after, Kozani 1996, 76-80, 1996.

Makropoulos, K. C.: The statistics of large earthquake magnitude and an evaluation of Greek seismicity, Ph.D. thesis, Univ. of Edinburgh, 1978.

Makropoulos, K. C. and Burton, P. W.: A catalog of seismicity in Greece and adjacent areas, Geophys. J. R. Astr. Soc., 65, 741$762,1981$.

Makropoulos, K. C. and Burton, P. W.: Greek Tectonics and Seismicity, Tectonophysics, 106, 275-304, 1984.

Makropoulos, K. C. and Burton, P. W.: Seismic Hazard in Greece: I Magnitude recurrence, Tectonophysics, 117, 205-257, 1985a.

Makropoulos, K. C. and Burton, P. W.: II Ground Acceleration, Tectonophysics, 117, 259-294, 1985b.

Makropoulos, K. C. and Burton, P. W.: "HAZAN": A Fortan program to evaluate seismic-hazard parameters using Gumbel's theory of extreme value statistics, Comput. Geosci., 12/1, 29-46, 1986.

Makropoulos, K. C., Drakopoulos, J. K., and Latoussakis, J. B.: A revised and extended earthquake catalog for Greece, since 1900, Geophys. J. Int., 98, 391-394, 1989.

Makropoulos, K. C., Kaviris, G., and Kouskouna, V.: An updated and extended earthquake catalogue for Greece and adjacent areas since 1900, Nat. Hazards Earth Syst. Sci., 12, 1425-1430, doi:10.5194/nhess-12-1425-2012, 2012.

Margaris, V., Papazachos, C., Papaioannou, Ch., Theodulidis, N., Kalogeras, I., and Skarlatoudis, A.: Ground motion attenuation relations for shallow earthquakes in Greece. Proc. 2nd Greek Conference on Earthquake Engineering and Engineering Seismology, Thessaloniki 28-30 November 2001, A, 27-36, 2001. 
Mercier, J.: I - Études géologique des zones internes des Hellénides en Macédoine Centrale (Grèce), II - Contribution à l'étude du métamorphisme et de l'évolution magmatiques des zones internes des Hellénides, Thèse Doct. Ès Sciences, Univ. Paris, 792 pp., 1966.

Meyer, B., Armijo, R., Massonnet, D., De Chebalier, J. B., Delacourt, C., Ruegg, J. C., Achache, J., Briole, P., and Papanastassiou, D.: The 1995 Grevena (Northern Greece) earthquake: fault model constrained with tectonic observations and SAR interferometry, Geophys. Res. Lett., 23, 2677-2680, 1996.

Mountrakis, D.: The Pelagonian zone in Greece: A polyphase deformed fragment of the Cimmerian Continent and its role in the geotectonic evolution of the Mediterranean, J. Geol., 94, 335347, 1986.

Mountrakis, D., Tranos, M., Papazachos, C., Thomaidou, E., Karagianni, E., and Vamvakaris, D.: "Neotectonic and seismological data concerning major activefaults, and the stress regimes of Northern Greece", Geological Society, London, Special Publications, 260, 649-670, 2006.

Ozturk, S., Bayrak, Y., Cinar, H., Koravos, G. C., and Tsapanos, T. M.: A quantitative appraisal of earthquake hazard parameters computed from Gumbel I method for different regions in and around Turkey, Nat. Hazards, 47, 471-495, 2008.

Papaioannou, Ch., Voulgaris, N., Karakaisis, G., Koutrakis, S., Latousakis, I., Makropoulos, K., Papazachos, B., Sokos, E., Stavrakakis, G., and Tselentis, G. A.: The Utilization of New Seismological Information in the Compilation of the New Seismic Hazard map of Greece, Proc. 3d Greek Conference on Earthquake Engineering and Engineering Seismology, Athens, 5-7 November 2008, article 2025, p. 19, 2008.

Papanastassiou, D., Drakatos, G., Voulgaris, N., and Stavrakakis, G.: The May 13, 1995, Kozani-Grevena earthquake: Source study and its tectonic implications, J. Geodynam., 26, 233-244, 1998.

Papazachos, B. C. and Comninakis, P. E.: A catalog of earthquakes in Greece and the surrounding area for the period 1901-1980, Publ. Univ. Thessaloniki, Geophys. Lab., 5, 1-146, 1982.
Papazachos, B. C. and Papazachou, C. B.: The Earthquakes of Greece, Ziti Publications, Thessaloniki, 304 pp., 1989.

Papazachos, B. C. and Papazachou, C. B.: The Earthquakes of Greece, Ziti Publications, Thessaloniki, 286 pp., 2003.

Pavlides, S., Zouros, N. Ch., Chatzipetros, A., Kostopoulos, D., and Mountrakis, D.: The 13 May 1995 Western Macedo nia, Greece, (Kozani-Grevena) earthquake: preliminary results, Terra Nova, 7, 544-549, 1995.

Pavlou, K.: Seismic activity and induced seismicity in Greece, $\mathrm{Ph}$ D. Thesis, Geophysics-Geothermics Department, Faculty of Geology and Geoenvironment, University of Athens, Greece, 2011 (in Greek).

R.D.: Royal Decree Code for Seismic Resistance (R.D.) of 19/26.2.1959 (FEK 36/A), About the Code for Seismic Resistance of Buildings, 1959.

Roeloffs, E. A.: Fault stability changes induced beneath a reservoir with Cyclic Variations in water level, J. Geophys. Res., 93, 21072124, 1988.

Shebalin, N. V., Karnik, V., and Hadzievski, D. (Eds): Balkan Region - Catalog of Earthquakes, UNESCO Project Office, Skopje, 1974.

Stepp, J. C.: An investigation of earthquake risk in the Puget Sound area by use of the type I distribution of largest extremes, PhD thesis, Pennsylvania State University, 131 pp., 1971.

Talwani, P. and Acree, S.: Pore pressure diffusion and the mechanism of reservoir-induced seismicity, Pure Appl. Geophys., 122, 947-964, 1985.

Theodulidis, N. and Papazachos, B.: Dependence of strong ground motion on magnitude-distance, site geology and macroseismic intensity for shallow earthquakes in Greece: I, Peak horizontal acceleration, velocity and displacement, Soil Dynam. Earth. Eng., 11, 387-402, 1992.

Tsapanos, T. M. and Burton, P. W.: Seismic hazard evaluation for specific seismic regions of the world, Tectonophysics, 194, 153169, 1991.

Withers, R. J. and Nyland, E.: Theory for rapid solution of ground subsidence near reservoirs on layered and porous media, Eng. Geol., 10, 169-185, 1976. 